\title{
Residual production of pineapple biomass under different levels of nitrogen and potassium in northwestern Paraná
}

\section{Produção residual de biomassa de abacaxi sob diferentes níveis de nitrogênio e potássio na região noroeste do Paraná}

\author{
Maria Elisa Vicentini ${ }^{1 *}$; Paulo Henrique Caramori²; \\ Sergio Luiz Colucci de Carvalho ${ }^{2}$; Luciano Grillo Gil'; \\ Wilma Aparecida Spinosa ${ }^{3}$; Geovanna Cristina Zaro"; \\ Wilian da Silva Ricce ${ }^{5}$; Alessandra Maria Detoni ${ }^{2}$
}

\begin{abstract}
Emphasis on studies that seek sustainable energy alternatives to oil has increased over the last few years. Ethanol derived from sugarcane remains a promising technology for biofuel production. Waste from pineapple culture remains is a potential alternative raw material for biofuel production. The goal of this study was to determine the potential of residual biomass production of a pineapple crop, subjected to fertilization by different levels of nitrogen and potassium. The experiment was conducted in Northwest Paraná, in a commercial area in Santa Isabel do Ivaí-PR. The climate in this area is subtropical humid according to the Köppen classification, and has a sandy dystrophic red acrisol.The experimental design was a $4 \times 4$ factorial, where factor $\mathrm{A}$ : $\mathrm{N}$ doses $\left(0 ; 11 ; 22\right.$; and $33 \mathrm{~g}$ per plant) and factor $\mathrm{B}: \mathrm{K}_{2} \mathrm{O}$ doses $(0$; $11 ; 22$; and $33 \mathrm{~g}$ per plant. The production of residual pineapple biomass responded differently to the $\mathrm{N}$ and $\mathrm{K}$ doses applied. Potassium fertilization had a positive linear correlation, up to the addition of $33 \mathrm{~g}$ plant $^{-1}$ with a production of $5.88 \mathrm{Mg} \mathrm{ha}^{-1}$. A dose of $18.138 \mathrm{~g} \mathrm{plant}^{-1}$ yielded in the maximum dry biomass production for nitrogen fertilization.
\end{abstract}

Key words: Biofuel, crop remains, Ananas comosus, fertilization

\section{Resumo}

Nos últimos anos intensificou-se a ênfase em estudos e pesquisas na busca de energias alternativas sustentáveis em relação ao petróleo. O etanol proveniente dos restos culturais tornou-se uma tecnologia promissora para produção de biocombustíveis. Dentre os resíduos agrícolas, os restos culturais do abacaxizeiro destacam-se como matéria-prima alternativa para este propósito. O objetivo deste trabalho foi determinar o potencial de produção de biomassa residual de uma lavoura de abacaxi, submetida a diferentes níveis de adubação nitrogenada e potássica. O experimento foi realizado na região Noroeste do Paraná, em uma área comercial em Santa Isabel do Ivaí-PR, de clima subtropical úmido segundo a classificação de Köppen, em um Argissolo Vermelho distrófico de textura arenosa. O delineamento

1 Eng ${ }^{\mathrm{a}} \mathrm{Agr}^{\mathrm{a}}$, M.e em Bioenergia, Universidade Estadual de Londrina, UEL, Londrina, PR, Brasil. Bolsista CAPES. E-mail: mevicentini@gmail.com

2 Eng $^{\text {os }}$ Agros , Pesquisadores, Instituto Agronômico do Paraná, IAPAR, Londrina, PR, Brasil. E-mail: pcaramori@gmail.com; slccarva@iapar.br; lggil@iapar.br; aledetoni@iapar.br

3 Eng ${ }^{a}$ Química, Prof $^{\mathrm{a}} \mathrm{Dr}^{\mathrm{a}}$, Dept ${ }^{\mathrm{o}}$ de Ciências e Tecnologia de Alimentos, UEL, Londrina, PR, Brasil. E-mail: wilma.spinosa@ gmail.com

4 Bióloga, M.e em Bioenergia, Bolsista FINEP/CNPq, Londrina, PR, Brasil. E-mail: geoczaro@gmail.com

5 Eng $^{\circ}$ Agr $^{\circ}$, Pesquisador da Empresa de Pesquisa Agropecuária e Extensão Rural de Santa Catarina, EPAGRI/CIRAM, Florianópolis, SC, Brasil. E-mail: wilianricce@epagri.sc.gov.br

* Author for correspondence 
experimental foi constituído em um fatorial $4 \mathrm{x} 4$, sendo o fator A: doses de $\mathrm{N}\left(0 ; 11 ; 22\right.$; e $\left.33 \mathrm{~g} \mathrm{planta}^{-1}\right) \mathrm{e}$ fator $\mathrm{B}$ : doses de $\mathrm{K}_{2} \mathrm{O}\left(0 ; 11 ; 22 ; \mathrm{e} 33 \mathrm{~g}_{\text {planta }}{ }^{-1}\right)$. A produção de biomassa residual de abacaxi apresentou respostas distintas às doses aplicadas de $\mathrm{N}$ e $\mathrm{K}$ na região noroeste do Paraná. A adubação potássica apresentou resposta linear crescente até $33 \mathrm{~g} \mathrm{planta}^{-1}$ com produção de 5,88 $\mathrm{Mg} \mathrm{ha}^{-1}$. Para a adubação nitrogenada a máxima produção de massa seca foi obtida com aplicação da dose de $18,138 \mathrm{~g} \mathrm{planta}^{-1}$.

Palavras-chave: Biocombustível, resto cultural, Ananas comosus, adubação

Agricultural production results in large quantities of waste that are not utilized for their energy. Brazil fails to take advantage of nearly 200 million tons of agro-industrial waste (CORTEZ et al., 2008). The raw material used to obtain $2 \mathrm{G}$ alcohol (second generation) comes from plant residues, including from agricultural waste (including sugarcane bagasse, straw, corn cobs, rice hulls, soybean hulls, and peanut hulls), and forest and agroindustrial residues (e.g., from the textile agribusiness and from fruit pulps). According to Mourad et al. (2004), the use of residual biomass to generate energy is beneficial to the environment, and adds value to the material in the form of fuel availability.

Pineapple crops are usually removed after fruit harvest and plantation is renewed in order to sustain sanity in the area. Thus, the incidence of pests and diseases during crop development is reduced. Industrialization of the pineapple plant yields the subproducts ethanol, and citric, malic and ascorbic acids. The pineapple plant emerges as a high quality raw material for ethanol production, with sugar contents of $4.7 \mathrm{Mg} \mathrm{ha}^{-1}$ (fruit) and $5 \mathrm{Mg} \mathrm{ha}^{-1}$ (leaf and stem) (CARVALHO et al., 1985).

Potassium (K) and nitrogen (N) are the most important nutrients and are particularly responsible for plant development and fruit quantity (GUARÇONI; VENTURA, 2011). Thus, this study aimed to determine the potential of residual pineapple biomass production, subject to different level of fertilization, to produce biofuel in the Northwest region of Paraná.

The experiment was conducted from September 2009 to June 2012, in a commercial area of Santa Isabel do Ivaí - PR (latitude 22 $57^{\prime} 52.35^{\prime}$ 'S, longitude $53^{\circ} 14^{\prime} 56.86^{\prime \prime} \mathrm{W}$ and an altitude of 470 $\mathrm{m})$. The climate in this region is humid subtropical (Cfa) according to the Köppen classification, with hot summers and temperatures above $22^{\circ} \mathrm{C}$. The soil is a typical sandy dystrophic red acrisol (PDv). Base saturation is less than $50 \%$ in most of the first $100 \mathrm{~cm}$ of horizon B. The soil had the following chemical characteristics at the beginning of the experiment: $\mathrm{pH}$ 5.2; $\mathrm{P}$ (Mehlich-1) $=4.8 \mathrm{mg} \mathrm{dm}^{-3}$; $\mathrm{K}=0.05 \mathrm{cmol}_{\mathrm{c}} \mathrm{dm}^{-3} ; \mathrm{Ca}=0.87 \mathrm{cmol}_{\mathrm{c}} \mathrm{dm}^{-3} ; \mathrm{Mg}=$ $0.65 \mathrm{cmol}_{\mathrm{c}} \mathrm{dm}^{-3} ; \mathrm{SB}=1.57 \mathrm{cmol}_{\mathrm{c}} \mathrm{dm}^{-3} ; \mathrm{CTC}=4.3$ $\mathrm{cmol}_{\mathrm{c}} \mathrm{dm}^{-3} ; \mathrm{H}+\mathrm{Al}=2.73 \mathrm{cmol}_{\mathrm{c}} \mathrm{dm}^{-3} ; \mathrm{Al}=0.0 \mathrm{cmol}_{\mathrm{c}}$ $\mathrm{dm}^{-3}$; and $\mathrm{V}(\%)=34.8$.

The experimental design consisted of randomized blocks (RB), with three replicates. The design was factorial $(4 \times 4)$, amounting to 16 treatments, where factor A consisted of $\mathrm{N}$ doses of $0 ; 11 ; 22$; and 33 g. $\mathrm{N}$ per plant, and factor $\mathrm{B}$ consisted of $\mathrm{K}_{2} \mathrm{O}$ doses of $0 ; 11 ; 22$; and $33 \mathrm{~g}$. $\mathrm{K}_{2} \mathrm{O}$ per plant. Soil $\mathrm{pH}$ was corrected by increasing base saturation to $60 \%$ with dolomitic limestone before beginning the plantation (in 2009).

A total of $6.5 \mathrm{~g}$ per plant of the formula $0-30$ 10 (N-P-K) was applied into the holes as the base fertilization. Plants were planted in the first half of September 2010. The double row planting system $(1.10 \times 0.40 \times 0.35 \mathrm{~m})$ was adopted, amounting to 38,095 plants $\mathrm{ha}^{-1}$. Each plot consisted of two rows (double row, 32 plants)-five useful plants and two double rows as margin.

Selected seedlings from the cultivar Smooth Cayenne (Hawaii) type slips were used; this is the most planted cultivar, and also has a base growth temperature $\left(15.8^{\circ} \mathrm{C}\right)$ well suited to the conditions of the Northwest region of Paraná (CARVALHO et al., 2005). The northwest, north, and west regions of the State are the most suitable for pineapple culture 
(cultivar Smooth Cayenne; Hawaii) because of lower climatic risks (RICCE et al., 2014). The seedlings were treated with the insecticide Imidacloprid $70 \% \mathrm{~m} / \mathrm{m}$, using the immersion technique as recommended by the manufacturer.

Nitrogen fertilizer was applied in the form of ammonium nitrate $\left(\mathrm{NH}_{4} \mathrm{NO}_{3} ; 34 \% \mathrm{~N}\right)$, and the potassium was applied in the form of potassium chloride $\left(\mathrm{KCl} ; 60 \% \mathrm{~K}_{2} \mathrm{O}\right)$. Applications were made in the ground near the axillary basal leaves, fractioned into four equal amounts. The applications were made 78, 154, 271, and 338 days after planting. All culture treatments were carried out as recommended during crop development.

The fruits were harvested, seedling types, slips, and suckers were removed, and the residual plant biomass in the field was collected 18 months after planting (March 2011). These residual plant biomass samples were dried in forced-air greenhouses until a constant biomass was reached and they were posteriorly weighed.

The residual dry biomass was estimated and then the production in $\mathrm{Mg} \mathrm{ha}^{-1}$ was estimated. The average dry biomass of the plants in the replicas was calculated and multiplied by the number of plants $\mathrm{ha}^{-1}$.

The results were analyzed using ANOVA ( $F$ test). The model with the best fit was selected by observing the significance of the regression performed using the T test.

The dose of $\mathrm{N}$ and $\mathrm{K}$ significantly affected the production of dry biomass in an independent manner (Table 1). For K, the highest production of dry biomass occurred at a dose of $33 \mathrm{~g}$ per plant. This concentration yielded $5.88 \mathrm{Mg} \mathrm{ha} \mathrm{h}^{-1}$, which corresponds to $1257 \mathrm{~kg}$ of $\mathrm{K}_{2} \mathrm{O}$ per ha-1 or $2.095 \mathrm{Mg}$ of $\mathrm{KCl}$ per ha-1 (Figure $1 \mathrm{~b}$ ).

Table 1. Summary of results from the dry biomass analysis of variance assay for pineapple treated with different levels of nitrogen and potassium.

\begin{tabular}{|c|c|c|c|c|}
\hline Source of variation & DF & SS & MS & $\operatorname{Pr}>$ Fc \\
\hline Block & 2 & 1.292081 & 0.646041 & 0.9140 .4119 \\
\hline Doses of $N(N)$ & 3 & 16.561638 & 5.520546 & $7.8090 .0005^{* *}$ \\
\hline Doses of $\mathrm{K}\left(\mathrm{K}_{2} \mathrm{O}\right)$ & 3 & 17.821312 & 5.940437 & $8.4030 .0003 * *$ \\
\hline $\mathrm{N} * \mathrm{~K}_{2} \mathrm{O}$ & 9 & 12.406346 & 1.378483 & $1.9500 .0824 \mathrm{n} / \mathrm{s}$ \\
\hline Error & 30 & 21.208555 & 0.706952 & \\
\hline Overall mean: & \multicolumn{3}{|c|}{54.290104} & \\
\hline $\mathrm{VC}(\%)$ & \multicolumn{3}{|c|}{15.49} & \\
\hline
\end{tabular}

** Significant at $5 \%$ probability by the $\mathrm{F}$ test, $\mathrm{n} / \mathrm{s}=$ not significant at $5 \%$ probability by the $\mathrm{F}$ test.

The potassium fertilization influenced the weight of the dry biomass. The results fit a linear regression model represented by the equation: dry biomass $\left(\mathrm{Mg} \mathrm{ha}^{-1}\right)=0.044 \mathrm{x}+4.7022$, with $\mathrm{R}^{2}=0.79$ (Figure 1b). Therefore, an increase of $0.044 \mathrm{Mg} \mathrm{ha}^{-1}$ dry biomass was observed for each gram of $\mathrm{K}_{2} \mathrm{O}$ added per plant.

Fruits are the main route of nutrient export. However, propagation material (wreaths and seedlings of slips and suckers types) also export nutrients (SOUZA; REINHARDT, 2009).

On average, a total of $178 \mathrm{~kg}$ of $\mathrm{N}, 21 \mathrm{~kg}$ of $\mathrm{P}$ (48 kg of $\mathrm{P}_{2} \mathrm{O}_{5}$ ), and $445 \mathrm{~kg}$ of $\mathrm{K}\left(536 \mathrm{~kg}\right.$ of $\mathrm{K}_{2} \mathrm{O}$ ) are extracted per hectare, leading to an average extraction of 1.0: 0.12: $2.5(\mathrm{~N}: \mathrm{P}: \mathrm{K})$ and 1.0: 0.27 : 3.0 (N: $\mathrm{P}_{2} \mathrm{O} 5: \mathrm{K}_{2} \mathrm{O}$ ) (SOUZA; REINHARDT, 2009). 
Figure 1. Effect of nitrogen $(\mathrm{N})(\mathrm{a})$ and potassium $\left(\mathrm{K}_{2} \mathrm{O}\right)(\mathrm{b})$ on the residual biomass.

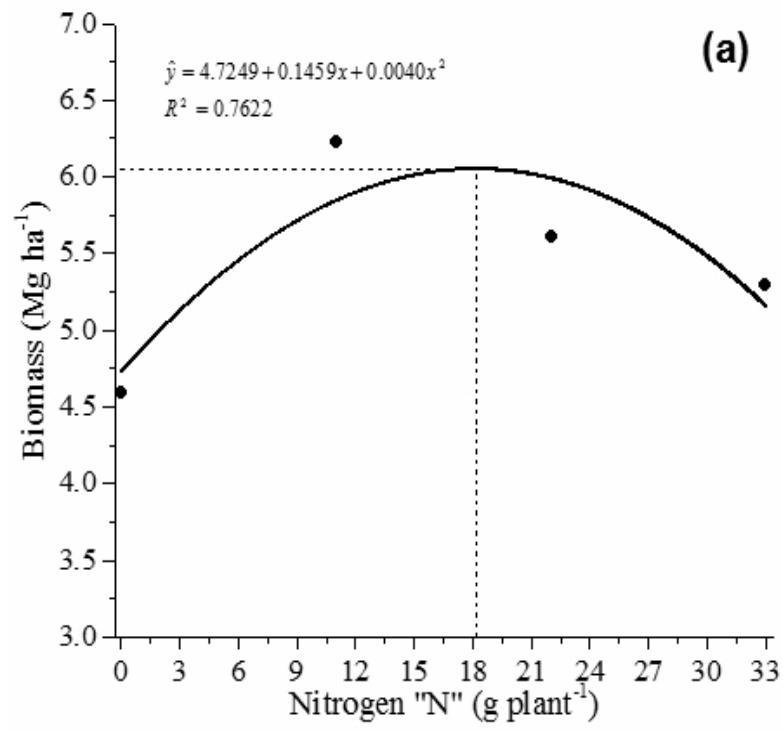

A higher dose of $\mathrm{K}$ contributes to the increase in biomass. However, there are no indications that $\mathrm{K}$ influences the average fruit weight or productivity. Gil et al. (2012) assessed the effects of $\mathrm{K}$ and $\mathrm{N}$ doses equal to those used in this study (under the same soil conditions) in fruit production. According to these authors, fruit yield per hectare and average fruit weight are influenced only by $\mathrm{N}$ fertilization, and the average wreath mass is not influenced by fertilization. In addition, Oliveira et al. (2013) reported that $\mathrm{K}$ fertilization did not influence productivity of the 'Imperial' pineapple orchard. Several authors studying different pineapple cultivars also reported similar results (TEIXEIRA et al., 2011; RODRIGUES, 2009).

The production of dry biomass showed a quadratic response to the dose of $\mathrm{N}$, following the equation: dry biomass $\left(\mathrm{Mg} \mathrm{ha}^{-1}\right)=4.7249+0.1459 \mathrm{x}$ $+0.0040 \mathrm{x}^{2}$, with $\mathrm{R}^{2}=0.762$ (Figure 1b). The maximum dry biomass production was estimated at $6.0478 \mathrm{Mg}$ per hectare, with the application of $18.138 \mathrm{~g}$ of $\mathrm{N}$ per plant. This $\mathrm{N}$ dose corresponds to approximately $690.96 \mathrm{~kg}$ of $\mathrm{N} \mathrm{ha}^{-1}$.

Nitrogen is the second highest sought nutrient by pineapple trees and, frequently, has controlled

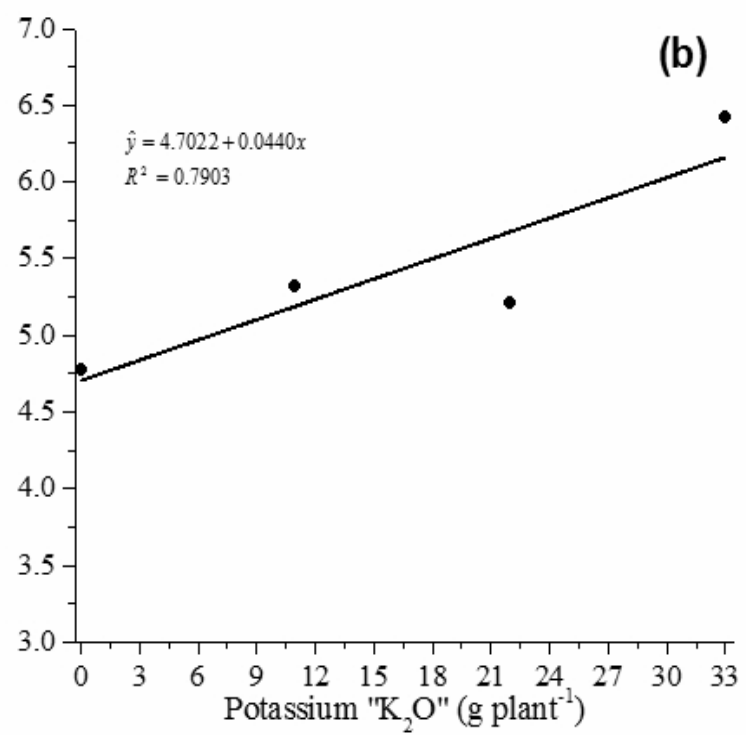

fruit yield of the crop (SOUZA; REINHARDT, 2009). Nitrogen carries out important functions in crassulacean acid metabolism (CAM), which are essential for their growth and development (SILVA et al., 2012).

Fertilization should be performed in the vegetative phase, where the highest rates of $\mathrm{N}$ accumulation occur in the plant (RIBEIRO et al., 2011). Caetano et al. (2013) noted that application of $\mathrm{N}$ doses above $320 \mathrm{~kg} \mathrm{ha}^{-1}$ is needed for maximum fruit weight and productivity. Marques et al. (2011), reported that $\mathrm{N}$ doses ranging from 250 to 1000 $\mathrm{kg} \mathrm{ha}^{-1}$ for the Smooth Cayenne cultivar lead to an increase in $\mathrm{N}$ accumulation in the leaves. However, the concentration of $\mathrm{N}$ fertilizer did not affect fruit productivity and quality.

In conclusion, the production of residual pineapple biomass responded differently to the doses of $\mathrm{N}$ and $\mathrm{K}$ applied to plants in the northwest region of Paraná. Potassium fertilization presented a positive linear correlation up to a dose of $33 \mathrm{~g}$ plant $^{-1}$ with a production of $5.88 \mathrm{Mg} \mathrm{ha}^{-1}$. The highest dry biomass production for nitrogen fertilization occurred following application at 18.138 g plant $^{-1}$ 


\section{Acknowledgments}

We thank CAPES for the Masters scholarship granted to the first author.

\section{References}

CAETANO, L. C. S.; VENTURA, J. A.; COSTA, A. F. S. C.; GUARÇONI, R. C. Efeito da adubação com nitrogênio, fosforo e potássio no desenvolvimento, na produção e na qualidade de frutos de abacaxi 'Vitoria'. Revista Brasileira de Fruticultura, Jaboticabal, v. 35, n. 3, p. 883-890, 2013.

CARVAlHO, S. L. C.; NEVES, C. S. V. J.; BURKLE, R.; MARUR, C. J. Épocas de indução floral e soma térmica do período do florescimento à colheita de abacaxi 'Smooth Cayenne'. Revista Brasileira de Fruticultura, Jaboticabal, v. 27, n. 3, p. 430-433, 2005.

CARVAlHO, V. D.; CUNHA, G. A. P.; PAULA, M. B.; CHITARRA, M. I. F. Teores de carboidratos no caule de algumas cultivares de abacaxi. Pesquisa Agropecuária Brasileira, Brasília, v. 20, n. 2, p. 197-200, 1985.

CORTEZ, L. A. B.; LORA, E. E. S.; GÓMEZ, E. O. Biomassa para energia. Campinas: Editora da Unicamp, 2008. 736 p.

GIL, L.; DETONI, A. M.; AULER, P. M. Nitrogênio e Potássio na indução floral natural do abacaxizeiro no noroeste do Paraná. In: FERTBIO, 2012, Maceió. Anais... Maceió, 2012. 4 p. CD-ROM.

GUARÇONI, A.; VENTURA, J. A. Adubação NPK e o desenvolvimento, produtividade e qualidade dos frutos do abacaxi 'gold'(md-2). Revista Brasileira de Ciência do Solo, Viçosa, MG, v. 35, n. 4, p. 1367-1376, 2011.

MARQUES, L. S.; ANDREOTTI, M.; BUZETTI, S.; ISEPON, J. S. Produtividade e qualidade de abacaxizeiro cv. Smooth Cayenne, cultivado com aplicação de doses e parcelamentos do nitrogênio, em Guaraçaí-SP. Revista Brasileira de Fruticultura, Jaboticabal, v. 33, n. 3, p. 1004-1014, 2011.

MOURAD, A. L.; AMBROGI, V. S.; GUERRA, S. M. G. Potencial de utilização energética de biomassa residual de grãos. In: ENCONTRO DE ENERGIA NO MEIO RURAL, 5., 2004, Campinas. Anais... Campinas, 2004. Disponível em: <http://www.proceedings.scielo.br/ scielo.phpscript $=$ sci_arttext\&pid=MSC0000000022004 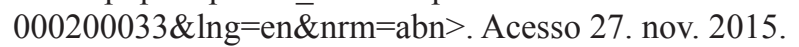
OLIVEIRA, A. M. G.; NATALE, W.; DÓRIA, J. O. Produção do abacaxizeiro 'Imperial' no extremo sul da Bahia, em função de doses de nitrogênio e potássio. In: CONGRESSO BRASILEIRO DE CIÊNCIA DO SOLO, 34., 2013, Florianópolis. Anais... Florianópolis, 2013. 4 p. CD-ROM.

RIBEIRO, D. G.; VASCONCELLOS, M. A. da; ARAÚJO, A. P. Contribuição do sistema radicular de mudas micropropagadas na absorção de nitrogênio de abacaxizeiro cultivar Vitória. Revista Brasileira de Fruticultura, Jaboticabal, v. 33, n. 4, p. 1240-1250, 2011.

RICCE, W. da S.; CARVALHO, S. L. C.; CARAMORI, P. H.; AULER, P. A. M.; ROBERTO, R. S. Zoneamento agroclimático da cultura do abacaxizeiro no Estado do Paraná. Revista Semina: Ciências Agrárias, Londrina, v. 35, n. 4, p. 2337-2346, 2014. Suplemento 1.

RODRIGUES, A. A. Nutrição mineral, produção, qualidade e análise econômica do abacaxizeiro cv. Pérola em função das relações K/N. 2009. Tese (Doutorado em Agronomia) - Universidade Federal da Paraíba, João Pessoa.

SILVA, A. L. P.; SILVA, A. P.; SOUZA A. P.; SANTOS, D.; SILVA, S. M.; SILVA, V. B. Resposta do abacaxizeiro'Vitoria' a doses de nitrogênio em solos de tabuleiros costeiros da Paraíba. Revista Brasileira de Ciência de Solo, Viçosa, MG, v. 36, n. 2, p. 447-456, 2012.

SOUZA, L. F. da S.; REINHARDT, D. H. R. C. Abacaxizeiro. In: CRISOSTOMO, L. A.; NAUMOV, A. (Org.). Adubando para alta produtividade e qualidade: fruteiras tropicais do Brasil. Fortaleza: Embrapa Agroindústria Tropical, 2009. p. 182-205.(IIP. Boletim, 18). Disponível em: <http://www.cnpat.embrapa.br/ cnpat/down/index.php?pub/Fruteiras TropicaisdoBrasil. pdf>. Acesso em: 27. nov.2014

TEIXEIRA, L. A. J.; QUAGGIO, J. A.; CANTARELLA, H.; MELLIS, E. V. Potassium fertilization for pineapple: effects on plant growth and fruit yield. Revista Brasileira de Fruticultura, Jaboticabal, v. 33, n. 2, p. 618-626, 2011. 
